\title{
PENGEMBANGAN GAME EDUKASI MOBILE MAKHLUK HIDUP KELAS REPTILIA UNTUK SISWA SMP
}

\author{
Risya Listya Rizalni ${ }^{1}$, Anggy Trisnadoli ${ }^{2}$, Muhammad Ihsan Zul ${ }^{3}$ \\ 1,2,3 Jurusan Teknologi Informasi, Politeknik Caltex Riau \\ Pekanbaru, Indonesia \\ e-mail: risya15ti@mahasiswa.pcr.ac.id¹ , anggy@pcr.ac.id ${ }^{2}$, insan@pcr.ac.id ${ }^{3}$
}

\begin{abstract}
Abstrak
Kelas reptilia merupakan bagian dari materi klasifikasi makhluk hidup yang terdapat pada mata pelajaran Biologi untuk siswa-siswi SMP kelas VII. Dalam proses belajar mengajar, media pembelajaran merupakan salah satu unsur terpenting selain metode pembelajaran. Manfaat media pembelajaran adalah melancarkan interaksi antara guru dengan siswa sehingga kegiatan pembelajaran akan lebih efektif dan efisien. Penyampaian materi pelajaran ini masih menggunakan sistem tradisional, sehingga kreativitas siswa kurang berkembang. Selain itu, untuk memahami ciri-ciri hewan kelas reptilia hanya dilihat dari gambar yang ada pada buku pelajaran. dan siswa sering mendapatkan nilai buruk bahkan harus melakukan remedial pada materi pelajaran tersebut. Oleh karena itu, dibangun sebuah game edukasi dengan tampilan model hewan 3D untuk pembelajaran materi klasifikasi makhluk hidup kelas reptilia. Berdasarkan pengujian manfaat belajar yang telah dilakukan ke siswa SMP kelas VII, didapatkan bahwa siswa yang menggunakan aplikasi game mengalami peningkatan pemahaman sebesar $40.5 \%$. Pada pengujian fungsional, didapatkan bahwa fungsi pada aplikasi dapat berjalan sesuai dengan hasil yang diharapkan. Serta berdasarkan pengujian umpan balik pengguna dapat disimpulkan bahwa game edukasi ini dapat membantu siswa dalam memahami materi perbedaan makhluk hidup berdasarkan ciri-ciri makhluk hidup kelas reptilia.
\end{abstract}

Kata kunci: Game Edukasi, Makhluk Hidup, Kelas Reptilia, Mobile Game

\begin{abstract}
Reptiles are part of material in Biology about classification living things for students at first grade in Junior High School. In teaching also learning process, media of learning is one of the most important methods for study. Benefit of it such as easier interaction between teachers also students so that learning process would be more effective and efficient. These days, learning process still use traditional system (mouth by mouth) so that student's creativity would less evolve. Other than that, to understand characteristic of reptiles only could be seen in the pictures of the book and students often got bad marks even must did remedial for that material. Therefore, an educational game with 3D model of animals was built for material in classification of living things. Based on benefits testing that already did to first grade students at Junior High School, it was found that students which experienced using game application increase their understanding material of reptiles about $40.5 \%$. In functional testing, it was found that functions in game application can work properly. And based on user feedback testing, it can be concluded that this educational game can help students understand material the difference between living things based on characteristic reptiles.
\end{abstract}

Keywords : Educational Games, Living things, Reptiles, Mobile Games 


\section{PENDAHULUAN}

Biologi adalah cabang dari IImu Pengetahuan Alam (IPA) yang khusus mempelajari tentang makhluk hidup [1]. Dalam pelajaran Biologi, pengelompokan makhluk hidup berdasarkan perbedaan dan persamaan cirinya disebut juga dengan klasifikasi [2]. Klasifikasi makhluk hidup merupakan salah satu bab pembelajaran pada siswa Sekolah Menengah Pertama (SMP) kelas VII. Dalam proses belajar mengajar, media pembelajaran merupakan salah satu unsur terpenting selain metode pembelajaran. Manfaat media pembelajaran adalah melancarkan interaksi antara guru dengan siswa sehingga kegiatan pembelajaran akan lebih efektif dan efisien [3]. Salah satu media pembelajaran yang menyenangkan adalah game edukasi. Game edukasi bertujuan untuk memancing minat belajar siswa terhadap materi pelajaran sambil bermain, sehingga diharapkan siswa bisa lebih mudah memahami materi pelajaran yang disajikan dengan perasaan senang. Game dapat mengajarkan banyak keterampilan kepada siswa dan dapat dijadikan sebagai salah satu alternatif pendidikan [4].

Berdasarkan hasil kuesioner yang telah peneliti lakukan kepada 5 guru IPA dan 30 siswa SMP kelas VII di salah satu SMP yang berada di kota Pekanbaru, provinsi Riau maka didapatkan $68 \%$ siswa dan $88 \%$ guru menyatakan bahwa penyampaian materi pelajaran bab klasifikasi makhluk hidup kelas reptilia masih menggunakan sistem tradisional (sistem ceramah) sehingga kreativitas siswa kurang berkembang dengan penyampaian materi menggunakan sistem tradisional tersebut. Serta $80 \%$ guru dan $74,6 \%$ siswa juga menyatakan bahwa untuk memahami ciri-ciri hewan kelas reptilia hanya dilihat dari gambar yang ada pada buku pelajaran. Menurut pra riset yang sama, berdasarkan persepsi guru sebesar $72 \%$ dan persepsi siswa sebesar 64\%, siswa sering mendapatkan nilai buruk bahkan harus melakukan remedial pada materi pelajaran tersebut. Hal tersebut menjadi permasalahan dalam mencapai indikator pencapaian siswa.
Berdasarkan permasalahan yang telah dipaparkan, maka dibutuhkan inovasi baru dalam pembelajaran untuk mendekatkan siswa dengan sarana teknologi dan menarik minat siswa dalam menunjang proses belajar pada bab pembelajaran klasifikasi makhluk hidup khususnya kelas reptilia, yaitu sebuah game edukasi. Game ini memiliki genre atau jenis game Adventure yang berjalan pada platform mobile, yaitu smartphone. Untuk pembangunan game ini menggunakan tools Unity dan tools Blender untuk proses modelling.

\section{KAJIAN TEORI}

\section{A. Game Edukasi Mobile}

Game adalah sebuah sistem yang memiliki kumpulan aturan-aturan buatan yang melibatkan pemain dengan bertujuan untuk menghibur. Game berisikan skenario yang tersusun dari kumpulan audio dan visual yang menarik sehingga membuat pengguna dapat menikmati jalannya permainan yang diberikan oleh permainan tersebut [5]. Istilah game edukasi pada dasarnya berasal dari Bahasa Inggris, yakni Game (Permainan) dan Edukasi (Pendidikan). Game edukasi adalah salah satu bentuk game yang dapat berguna untuk menunjang proses belajar-mengajar secara lebih menyenangkan dan lebih kreatif, dan digunakan untuk memberikan pengajaran atau menambah pengetahuan penggunanya melalui suatu media yang menarik [6].

B. Klasifikasi Makhluk Hidup Kelas Reptilia Perkembangan ilmu klasifikasi berasal dari seorang ahli Biologi Swedia, Carolus Linnaeus. Salah satu cara pengelompokan yang banyak dipakai dalam Biologi adalah sistem pengelompokkan oleh Robert $\mathrm{H}$. Whittaker pada 1969. la mengelompokkan makhluk hidup dalam lima kelompok besar atau kingdom, yaitu Monera, Protista, jamur (Fungi), tumbuhan (Plantae), dan hewan (Animalia). Salah satu kingdom pada makhluk hidup adalah Kingdom Animalia. Dalam sistem pengelompokan Kingdom Animalia (hewan), hewan dapat dikelompokkan menjadi kelompok hewan tidak bertulang belakang (Invertebrata) dan kelompok hewan bertulang belakang (Vertebrata) [7]. Kelas Reptilia termasuk 
kedalam kelompok hewan bertulang belakang (Vertebrata). Pada kelas Reptilia dibagi menjadi 4 ordo (pengelompokan), yaitu Ordo Squamata, Ordo Rhynchocephalia, Ordo Testudinata dan Ordo Crocodila [2].

\section{METODOLOGI PENELITIAN}

Tahapan-tahapan yang dilakukan dalam pengembangan game edukasi dibagi menjadi 4 bagian yaitu pre-production, production, testing dan post-production, seperti pada gambar 1 .

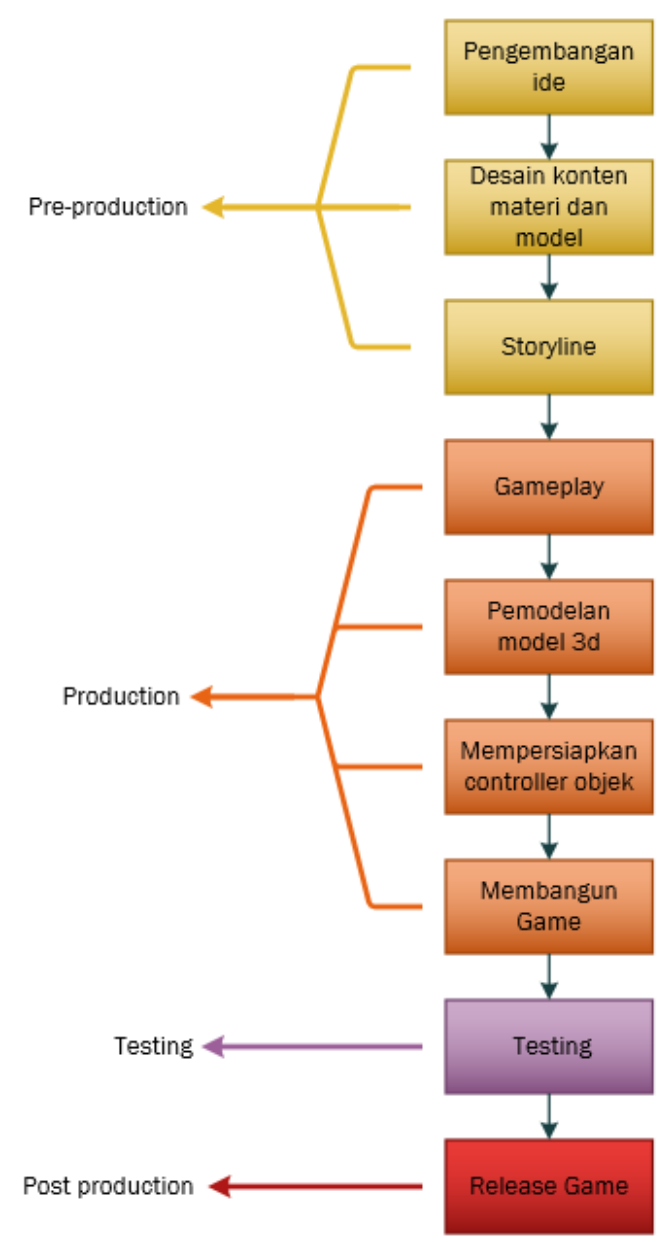

Gambar 1. Tahapan Pengembangan Permainan

Gambar 1. merupakan blok diagram sebagai tahapan pengembangan game edukasi makhluk hidup kelas reptilia. Berikut adalah tahapan membuat game edukasi pada penelitian ini.

1. Tahapan Pre-production
Tahapan pertama yaitu menyusun ide game edukasi dalam bentuk pengembangan ide atau perancangan interface, desain konten materi dan model serta membuat storyline.

\section{Tahapan Production}

Setelah dilakukan tahap pertama, maka dilakukanlah tahapan production dengan membuat gameplay, membuat pemodelan tiga dimensi di blender dan mempersiapkan kontrol yang akan menjadi tombol pada permainan yang akan dimainkan. Soal dan pertanyan yang dibuat pada game juga dibangun pada tahap production. Sound dan tingkatan level pada game termasuk juga ke tahapan production dalam pembuatan game.

\section{Tahapan Testing}

Tahapan selajutnya adalah tahapan testing yaitu dengan melakukan berbagai testing. Tahapan testing dilakukan untuk menemukan bug pada pengembangan game edukasi. Pada proyek akhir ini terdapat beberapa testing atau pengujian, seperti pengujian berupa validasi model tiga dimensi hewan reptilia ke ahli pakar, pengujian fungsionalitas, pengujian manfaat belajar dengan game edukasi dan tanpa game edukasi dan pengujian umpan balik pengguna menggunakan kuesioner.

\section{Tahapan Post-production}

Tahapan terakhir pada pembangunan game ini adalah postproduction yaitu tahapan pemeliharaan game setelah game versi live telah di rilis.

\section{HASIL DAN PEMBAHASAN}

Salah satu hasil luaran dari penelitian ini adalah produk aplikasi game edukasi mobile makhluk hidup kelas reptilia. Berikut adalah beberapa tampilan aplikasi game yang telah dikembangkan.

1) Tampilan Menu Utama

Gambar 2 merupakan tampilan menu utama game edukasi. Pada menu utama ini terdapat 5 tombol yang terdiri dari tombol Belajar, Mulai, Petunjuk, Nilai, dan Keluar. 


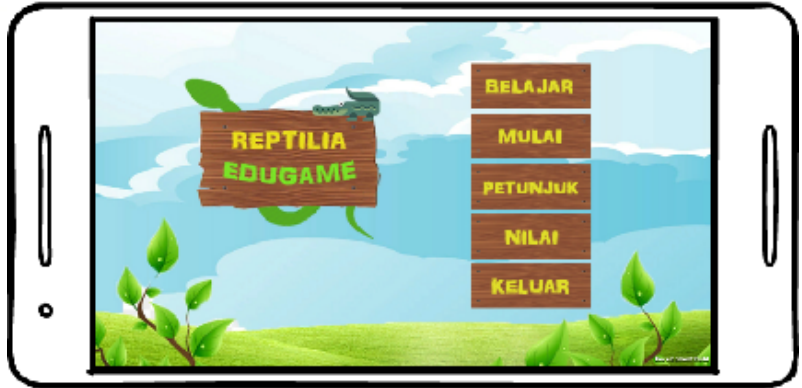

Gambar 2. Tampilan Menu Utama

2) Tampilan Menu Belajar

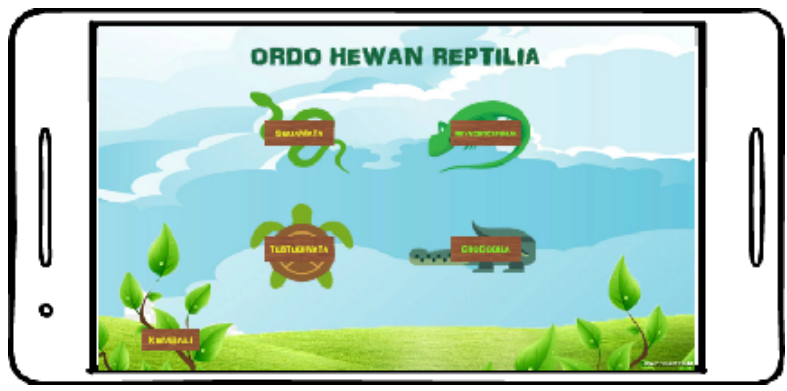

Gambar 3. Tampilan Menu Belajar

Gambar 3 merupakan Tampilan untuk memilih materi ordo hewan reptilia yang terdiri dari Squamata, Rhynchocephalia, Testudinata dan Crocodila. Jika pemain memilih salah satu materi ordo, maka akan menampilkan informasi dari ordo hewan reptilia yang dipilih tersebut.

3) Tampilan informasi salah satu hewan reptilia

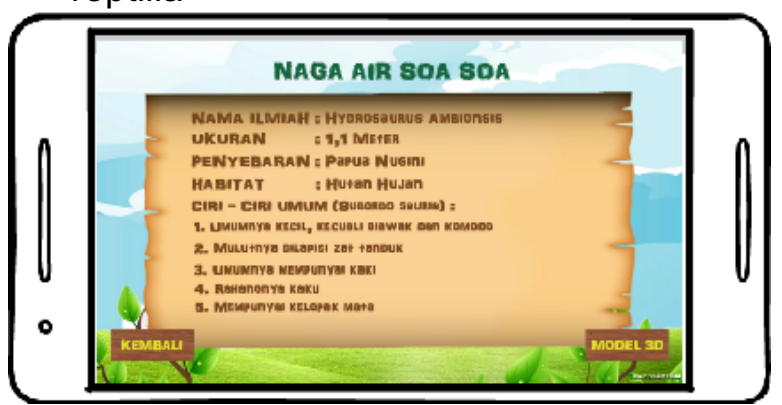

Gambar 4. Tampilan informasi hewan Naga Air Soa Soa

Gambar 4 merupakan tampilan informasi salah satu contoh hewan reptilia dari salah satu subordo pada ordo squamata yaitu Naga Air Soa Soa. Jika di klik tombol model 3D, maka akan menampilkan tampilan pemodelan hewan tiga dimensi dari Naga Air Soa Soa seperti pada gambar 5.

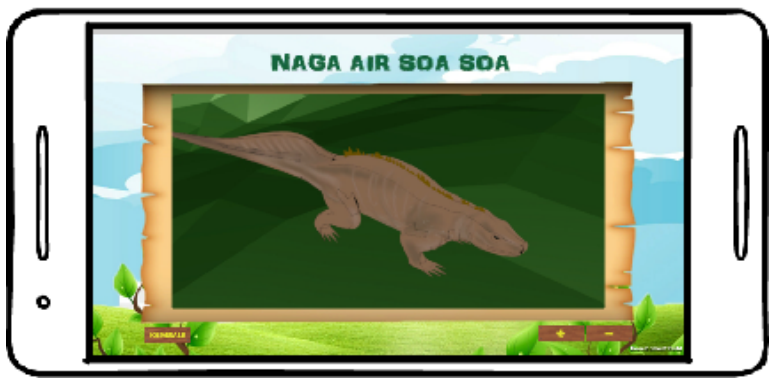

Gambar 5. Tampilan Pemodelan 3D pada hewan Naga Air Soa Soa

4) Tampilan Bermain Game Edukasi

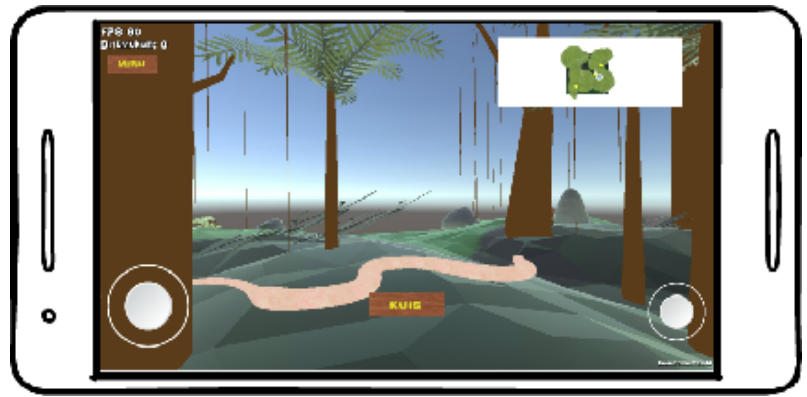

Gambar 6. Tampilan game di level 1

Gambar 6 merupakan tampilan saat bermain game, pemain harus menemukan hewan reptilia di dalam hutan tersebut. Jika pemain menemukan satu hewan, maka pemain harus menjawab 1 soal kuis. Saat pemain menekan tombol kuis, akan muncul soal kuis tentang hewan tersebut dan pemain harus menjawab soal kuis tersebut, seperti pada Gambar 7. Untuk memainkan game ini pemain menggunakan dua buah tombol joystick bantuan.

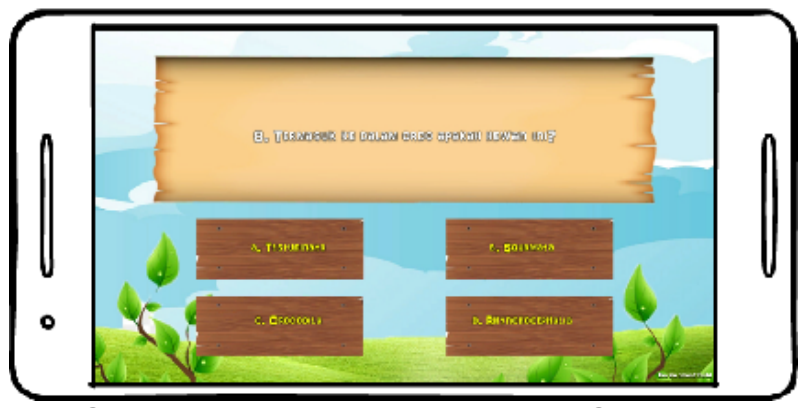

Gambar 7. Tampilan Aplikasi Game 


\section{PENGUJIAN DAN ANALISIS}

Untuk memastikan bahwa penelitian ini sudah berjalan sesuai dengan tujuan yang diharapkan, maka dilakukan beberapa pengujian sehingga nantinya dapat mengonfirmasi hasil yang telah diberikan. Terdapat empat jenis pengujian yang dilakukan seperti Validasi Model 3D kepada Pakar Biologi, Pengujian Fungsional Produk Aplikasi Game, Pengujian Pemanfaatan dalam Proses Belajar Mengajar, dan Umpan Balik Pengguna.

\section{A. Validasi Model 3 Dimensi}

Validasi model 3 dimensi hewan reptilia dilakukan kepada pakar dalam bidang Biologi, salah satunya adalah seorang dosen Struktur Perkembangan Hewan dari Fakultas IImu Pendidikan Biologi (FKIP) dari Universitas yang berada di Provinsi Riau.

Validasi ini dilakukan dengan proses sebagai berikut:

1. Melihatkan gambar referensi dan hasil pemodelan tiga dimensi hewan reptilia.

2. Pakar membandingkan gambar dan hasil pemodelan tiga dimensi yang sudah dikerjakan

3. Pakar memberi masukan ataupun komentar.

Validasi model 3 dimensi dilakukan dalam dua tahapan, yaitu tahapan pertama dilakukan pada 4 Februari 2019. Hasil tahapan ini didapatkan bahwa 9 dari 11 model simulasi diterima. Selain dari itu, 2 model lain perlu diperbaiki, yaitu hewan Kadal Cacing berkaki dua dan Aligator Amerika, sehingga dibutuhkan tahapan validasi kedua. Tahapan kedua dilakukan pada 6 Februari 2019 dengan hasil didapatkan bahwa model tiga dimensi hewan reptilia sudah layak untuk ditampilkan kepada siswa kelas VII (tujuh) SMP.

\section{B. Pengujian Fungsional Produk Game}

Pengujian Fungsioal pada produk game dilakukan bersama salah satu Guru IPA di SMP Negeri yang ada di Kota Pekanbaru untuk menguji seluruh fungsi-fungsi yang ada pada game telah sesuai dengan kebutuhan yang diharapkan sejak awal, serta untuk mengetahui apakah game yang dikembangkan dapat berjalan sesuai dengan output yang diharapkan.

Setiap fungsi yang ada pada game dicatat dalam tabel test case lalu diujikan sesuai dengan skenario game. Fungsi yang berhasil dijalankan, dicatat dengan keterangan valid. Sementara fungsi yang masih terdapat error, dicatat bagian error dari fungsi tersebut pada kolom catatan dan dicatat dengan keterangan tidak valid.

Berdasarkan hasil dari pengujian yang telah dilakukan, dapat disimpulkan bahwa seluruh fungsi pada produk aplikasi game edukasi makhluk hidup kelas reptilia yang telah dikembangkan dinyatakan telah sesuai dengan output yang diharapkan.

\section{Pengujian Manfaat Produk dalam Proses Belajar Mengajar}

Prngujian ini dilakukan untuk membuktikan apakah manfaat dari produk yang dikembangkan dapat memilki manfaat seara langsung yang dirasakan olh pegguna, dalam hal ini adalah siswa-siswi SMP kelas VII. Kelas ini dipilih karena dalam kurikulumnya materi Klasifikasi Makhluk Hidup Kelas Reptilia diajarkan pada tahun tersebut namun belum mendapatkan materi ini dikelas.

Pengujian ini dilakukan bersama 42 siswa. Siswa diberikan lembaran soal pertama yang berisi 15 soal untuk mengetahui pemahaman mereka sebelum menggunakan aplikasi game edukasi. Kemudian siswa diberikan waktu untuk menggunakan aplikasi game edukasi dalam beberapa waktu, sehingga siswa dapat mengeksplorasi permainan dengan cara yang menyenangkan oleh mereka sendiri.

Setelah dianggap cukup bermain, kemudian siswa tersebut kembali diberikan lembar soal kedua yang berbeda. Masingmasing responden menjawab 15 soal tersebut pada kumpulan soal pertama dan kumpulan soal kedua. Setiap jawaban benar akan diberikan nilai 1 , dan jika jawaban salah diberi nilai 0 . 
Berdasarkan hasil dari perhitungan nilai tersebut, maka dapat dibandingakn nilai siswa pada saat sebelum menggunakan Permainan, dan setelah memainkan game edukasi ini. Hasil perbandingan tersebut dapat dilihat pada Tabel 1 berikut.

Tabel 1. Perbandingan Nilai Responden

\begin{tabular}{ccc}
\hline & $\begin{array}{c}\text { Sebelum } \\
\text { Bermain }\end{array}$ & $\begin{array}{c}\text { Setelah } \\
\text { Bermain }\end{array}$ \\
\hline Nilai Rata-rata & 5,05 & 11,12 \\
\hline Persentase (\%) & $\mathbf{3 3 , 6 5 \%}$ & $\mathbf{7 4 , 1 3 \%}$ \\
\hline
\end{tabular}

Berdasarkan hasil nilai yang didapat, rata-rata nilai didapatkan sebesar $33,65 \%$ dan $74,13 \%$ sehingga dapat dilihat pergerakannya seperti pada Gambar 8 berikut.

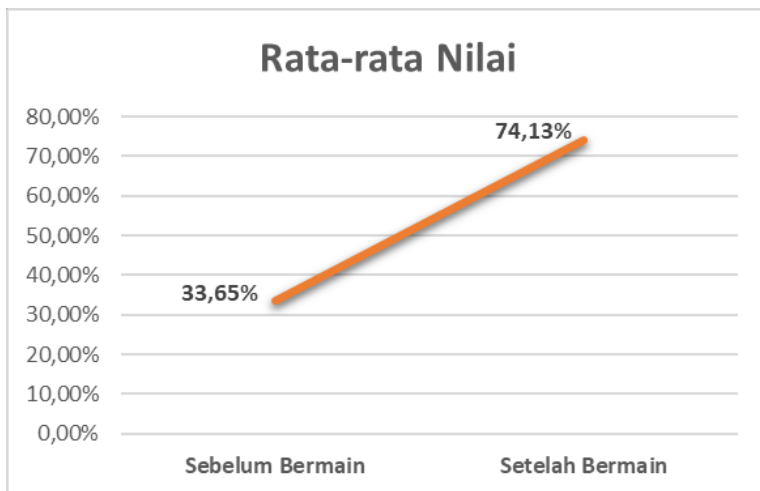

Gambar 8. Kenaikan nilai setelah menggunakan Aplikasi Game

Berdasarkan gambar 8 tersebut, terlihat terjadi kenaikan antara hasil sebelum menggunakan game dan setelah menggunakan aplikasi game sebesar adalah $40,45 \%$. Sehingga dapat disimpulkan bahwa siswa dapat meningkatkan pemahaman pelajaran makhluk hidup kelas reptilia setelah mereka bermain dengan menggunakan aplikasi game edukasi ini.

\section{Pengujian Umpan Balik Pengguna}

Pengujian umpan balik pengguna dilakukan untuk mendapatkan kesan dan masukan dari pengguna untuk pengembangan aplikasi game yang telah dibuat. Pengumpulan data umpan balik pengguna ini dilakukan dengan menggunakan kuesioner dengan perhitungan metode skala likert.
Responden merupakan 42 orang siswasiswi yang sama yang dinilai pada pengujian sebelmnya. Bagian-bagian yang menjadi konsentrasi dalam kuesioner yang diberikan adalah ketertarikan dengan antarmuka aplikasi game edukas, kemudahan penggunaan, pengaturan navigasi, Kkesesuaian dan kemudahan bahasa untuk dimengerti, hingga maanfaat game dari segi peningkatan pemahaman.

Berikut pada tabel 2 merupakan presentase hasil umpan balik siswa tersebut.

Tabel 2. Hasil Umpan Balik Responden

\begin{tabular}{ccc}
\hline Indikator & $\begin{array}{c}\text { Presentase } \\
(\mathbf{\%})\end{array}$ & Keterangan \\
\hline 1 & $79,52 \%$ & Baik \\
2 & $80 \%$ & Baik \\
3 & $76,67 \%$ & Baik \\
4 & $78,09 \%$ & Baik \\
5 & $79,04 \%$ & Baik \\
6 & $83,33 \%$ & Baik \\
7 & $89,04 \%$ & Sangat Baik \\
\hline Rata-rata & $80,81 \%$ & Baik \\
\hline
\end{tabular}

Berdasarkan hasil pengujian yang dilakukan menggunakan perhitungan skala likert, didapatkan bahwa hasil umpan balik respinden menghasilkan nilai presentase diatas $75 \%$ dan perhitungan rata-rata dari tujuh pernyataan tersebut menghasilkan nilai presentase sebesar $80,81 \%$. Sehingga dapat disimpulkan bahwa aplikasi game ini berada pada kriteria yang baik.

\section{SIMPULAN}

Adapun kesimpulan dari penelitian ini adalah produk game edukasi mobile yang dibangun dapat memberikan manfaat yang baik dalam peningkatan pemahaman pengguna untuk materi biologi khususnya reptilia. Hal tersebut diunjukkan dengan hasil pengujian untuk peningkatan nilai ratarata sebesar 40,45\%, Model 3 Dimensi yang dinyatakan valid sudah sesuai oleh Pakar Biologi, fungsional yang telah sesuai dengan apa yang diharapkan oleh guru SMP untuk bidang biologi, serta umpan balik yang baik dari seluruh responden. 
Adapun saran pengembangan yang dapat dilakukan pada penelitian yang akan datang materi pada aplikasi game edukasi bisa dikembangkan untuk tingkat Sekolah Menengah Atas (SMA). Serta Aplikasi game dapat dibuat untuk versi sistem operasi lainnya seperti IOS, sehingga dapat menjangkau seluruh pengguna mobile device.

\section{REFERENSI}

[1] Suwarno, Panduan Pembelajaran Biologi untuk SMP, Jakarta: CV Karya Mandiri Nusantara, 2009.

[2] L. S. Astuti, Klasifikasi Hewan, Jakarta: PT Kawan Pustaka, 2007.

[3] K. N. Cittalaksana, "Pengembangan Multimedia Pembelajaran untuk Mata Pelajaran Pkn Kelas VII di SMP Negeri 1 Melaya", E-Jurnal Edutech Universitas Pendidikan Ganesha, 2014.
[4] D. Buckingham and M. Scanlon, "Interactivity and Pedagogy in "Edutainment" Software", Information Technology, Education and Society, 107-126, 2003.

[5] A. Trisnadoli, B. Hendradjaya and W. D. Sunindyo, "A proposal of quality model for mobile games", 2015 International Conference on Electrical Engineering and Informatics (ICEEI), 377-381, 2015.

[6] D. A. P. Dewi and S. C. Wibawa, "Pengembangan Game Edukasi "Khrisna Adventure" Dengan Metode Pembelajaran Menyenangkan (Joyful Learning)", IT-EDU, 155-161, 2017.

[7] S. Karim. dkk, Belajar IPA Membuka cakrawala Alam Sekitar, Penerbit PT. Setia Purna Inves, 2009. 